\title{
Household food insecurity and coping strategies in Southern Ethiopia
}

\author{
Mesfin Melese ${ }^{1}$, Minyahel Tilahun ${ }^{1 *}$ (i) and Mebratu Alemu²
}

\begin{abstract}
Background: Hunger and undernourishment are the main challenges of today's world and 960 million people are hungry and undernourished. Food insecurity is an enduring, critical challenge in Ethiopia. Majority of the previous studies overlooked relevant determinant factors which affect the occurrence of food insecurity. This study aims to investigate household level food insecurity determinate factors and coping strategies used in the study area.

Method: Explanatory and descriptive research was designed to assess household food insecurity and coping strategies in Analemmo district of southern Ethiopia. A multi-stage purposive sampling technique was used for the purpose of this study. Two hundred households were selected systematically following list of food insecure households. Econometric models were employed using binary logit model. Household calorie acquisition was calculated to categorize households into food secure and food insecurely status.

Results: The survey result showed that $64 \%$ of the respondents were food insecure. Variables such as agro-ecology, age and education status, number of oxen, soil and water conservation, amount of credit, cultivated land size and receiving remittance were negatively but significantly $(P<0.05)$ affected households'food insecurity level. Female and young groups of the community were more food insecure as compared to others groups. The community was coping food shortage by relying on less preferred and less expensive food followed by participating in off-farm activities and borrowing food. Housesholds in the study area were utilizing less preferred foods to cope up food shortage and starvation.
\end{abstract}

Conclusion: Efforts of different developmental organizations should give due emphasis to household's wealth level, female-headed household and young and old-aged members of the community. Crop land production supported by modern agricultural technologies and information can reduce agricultural risks, and enhance productivity per unit land.

Keywords: Calorie acquisition, Coping strategies, Farmers' experience, Food insecurity, Logit model

\section{Background}

Hunger and undernourishment are the main challenges of today's world and 960 million people are hungry and undernourished [1]. The severity of the challenge is very high in developing and tropical countries [2]. Majority of the African countries has been hosting frequent and

*Correspondence: ftminyahil@gmail.com; minyahel.tilahun@wku.edu.et

${ }^{1}$ College of Agriculture and Natural Resource, Wolkite University, P.O.box 07, Wolkite, Ethiopia

Full list of author information is available at the end of the article sever hunger and undernourishment. Of the total African population, $27.4 \%$ is found under chronic food insecurity problem which is four times more than any other continent in the world [3]. Among the African countries, Ethiopia has the highest prevalence of undernourishment (32.1 million people) from Sub-Saharan Africa followed by Tanzania (15.7 million), Nigeria (12.1 million), Kenya (11 million) and Uganda (10.7 million) [4, 5].

The main cause of food shortage in Ethiopia is natural disaster, severe drought, flooding, insecurity, and conflict. These causes have been worsening and leading to 
rapid and large-scale displacement along the borders of Somali, Oromia, and SNNPR [6]. In the ever-continuing quest for finding a suitable and effective remedy against failure of rainfall, researchers have analyzed coping strategies that have been used by different communities from different production system for long periods [7, 8]. Rural households (HHs) in Ethiopia have been using food insecurity coping strategies such as selling of live animals to purchasing food grain, borrowing, participate in off-farm activities, seeking relatives and friends support, change in feeding habit, food for work, reducing the amount to be consumed [9-11]. The importance of focusing on those local indicators can help farmers to develop early warning systems which minimize the negative impact of factors such as climate change. Basically, others $[8,12,13]$ have shown that inter-annual rainfall variability followed by extreme forage fluctuations can cause greater damage on the productivity of crops and livestock, and also further increase livestock population die-off.

Food insecurity is an enduring, critical challenge in the Federal Democratic Republic of Ethiopia [6]. Rural poverty and food insecurity were challenging for millions of people in the country. Fifty two percent of the country population is food insecure with an average $\mathrm{HH}$ consumption of 1770 kilocalories per adult equivalent which is less below national recommended daily kilocalories of 2100 [14]. In southern Ethiopia, on average, 22\% of the total HHs lives below the food poverty line [15]. The situation is so much worse in zones such as Hadiya
[16]. For long, Ethiopian governments has been implementing policies and programs relevant for food security and nutrition including GTP 2010-2015, the agriculture sector policy and investment framework (PIF) and food security programs (2010-2014). In addition, more than 60 percent of the daily calorie intake in Ethiopia is derived from five cereal crops namely, teff, barley, wheat, maize, and sorghum. Food balance sheet shows, per capita supply of food for the $2017 / 18$ period is $202 \mathrm{~kg} /$ year/ person which is below the recommended rate of $218 \mathrm{~kg} /$ person/year [17]. There have been studies [18, 19] which deal about determinants and coping strategies of food insecure $\mathrm{HH}$. However, those studies overlooked relevant variables such as agro-ecology, access to irrigation, soil and water conservation and non-farm income. Moreover, they did not consider the coping strategies index to examine how food insecure HHs mitigate food shortage. Therefore, this study aims to investigate $\mathrm{HH}$ food insecurity determinate factors and coping strategies of the $\mathrm{HH}$ to cope food shortage in the study area.

\section{Materials and methods \\ Description of the study area}

This study was conducted in Hadiya Zone, Ethiopia. It is $214 \mathrm{kms}$ from the capital city, Addis Ababa. For the purpose of this study, Analemmo district was selected and it is geographically located between $70^{\circ} 54^{\prime}-70^{\circ} 73^{\prime}$ latitudes and $370^{\circ} 89^{\prime}-380^{\circ} 06^{\prime}$ longitudes [20]. It consists of 27 rural Peasant Associations (Kebeles). Kebeles are

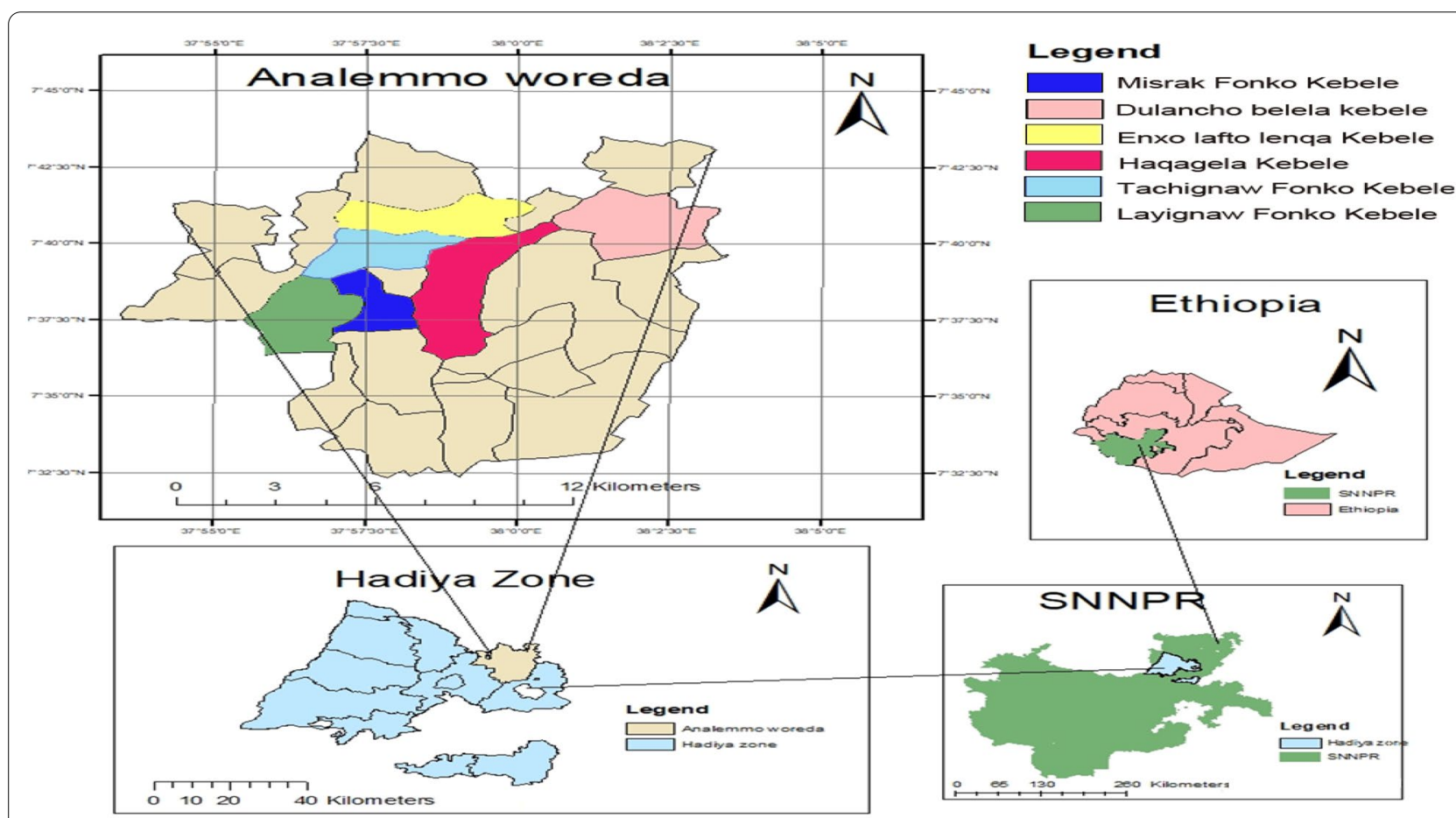

Fig. 1 The administrative map of Analemmo district (Woreda) 
the lowest administration level of the country. The district has two agro-climatic zones namely Lowland (Kola) and Midland (Woina Dega), covers 40 and 60 percent of the land mass, respectively. The totals $\mathrm{HHs}$ of the target population within the 27 kebeles are found to be 11,116 [20]. Mixed cropping system is majorly practiced in the district. The major cereal and pulse crops are teff, barley, wheat, maize; sorghum, bean, and haricot bean are produced commonly in long rain (Meher) season. The mean annual rainfall of the area ranges from $1000 \mathrm{~mm}$ to $1400 \mathrm{~mm}$, and the mean annual temperature ranges from $15{ }^{\circ} \mathrm{C}$ to $20{ }^{\circ} \mathrm{C}$. The administrative map of Analemmo district is presented in the figure below (Fig. 1).

\section{Research design}

For this study, descriptive and explanatory research design that followed a cross-sectional survey was employed. Households were selected based on three stage sampling design. The design was used to collect both qualitative and quantitative data. Participatory Rural Appraisal (PRA) tools that incorporated formal survey, Key Informants Interview (KII), personal observation, and Focus Group Discussion (FGD) were employed to triangulate the accuracy of the collected data.

\section{Sampling techniques and sample size determination}

The sampling was done following three stages. Originally, the kebeles within the district was categorized in to two major agro ecological categories i.e., midland and lowland. Then, among the two agro-ecological categories, two kebeles from the lowland and four kebeles from the midland were selected purposively based on the frequency of drought occurrence, level of food insecure and relative number of safety net program beneficiaries. Proportionally, majority of Ethiopian rural population dwell in midland agro-ecologies. The sample HH's size was determined based on the formula by [21] as cited by [22] as follows.

$$
n=\frac{N}{1+N(e)^{2}},
$$

Table 1 Description of the $\mathrm{HH}$ representatives and HHs food security status $(N=200)$

\begin{tabular}{llllll}
\hline HHs food insecurity status & Frequency (\%) & Mean & S.D & Min & Max \\
\hline Food secure (FS) & $72(36)$ & 2858.75 & 810 & 432 & 5271 \\
Food insecure (FIS) & $128(64)$ & 1465.11 & 422 & & \\
Total & $200(100)$ & 1966.82 & 893 & & \\
\hline
\end{tabular}

$$
n=\frac{11116}{1+11116(0.07)^{2}}=200,
$$

where $n$ is sample size, $\mathrm{N}$ is the total population, 1 is the constant $e=$ margin of error $(e=0.07)$. Eventually, 200 $\mathrm{HHs}$ were selected from list of $\mathrm{HHs}$ dwell in the selected kebeles systematically to represent $\mathrm{HHs}$ in different kebeles of the district. The households were selected systematically following every 14th household from the list of $\mathrm{HHs}$ collected from all the six kebeles.

\section{Data sources and data collection methods}

Both primary and secondary data sources were used. The primary data were collected from sample HHs through formal survey. Semi-structured questionnaires in the form of paper were developed to get first-hand information about food security status and determinant of food insecurity. Furthermore, six FGDs and 11 KIIs were done. Secondary data were collected from different published and unpublished documents and used for interpretation and discussion purpose.

\section{Data analysis}

The collected and completed questionnaires were first checked and coded. Data were entered into computer and analyzed using STATA version 14 software programs after careful scrutiny. Data regarding $\mathrm{HH}$ food consumption level within 7 days were converted in to kilocalorie following nationally recommended kilocalorie by [23]. Household's daily calorie intake per adult equivalent was calculated by dividing the HH's daily calorie intake to the family size after adjusting for adult equivalent using the consumption factor for age-sex categories [24]. Households who consumed below this minimum requirement (i.e., $2100 \mathrm{kcal}$ per adult equivalent per day) were categorized as food insecure and those HHs who consumed above the threshold were considered as food secure. Therefore, Out of the total 200 respondents, 128 of the total HHs were food insecure and the rest 72 were food secure (Table 1).

Coping strategy index (CSI) was calculated based on the ranks of local coping strategies adopted using Weighted Mean Score. A four-point scale with the scoring order of 3, 2, 1, 0 for frequently, sometimes, rarely and never was used to calculate frequency of $\mathrm{HH}$ reliance on various coping strategies [25].

$$
\mathrm{CSI}=N_{3} X_{3}+N_{2} X_{2}+N_{1} X_{1}+N_{0} X_{0},
$$

where $N_{\mathrm{i}}=$ number of the HHs using a particular coping strategy and $X \mathrm{i}=$ scoring order for frequency. The CSI was used in rank order to reflect the comparative position of each of the coping strategy in terms of use. Weighted Mean Score (WMS) was calculated: 


$$
\mathrm{WMS}_{\mathrm{i}}=\frac{\mathrm{CSI}}{Z},
$$

WMS = weighted mean score $Z=$ a total number of $\mathrm{HH}$ head and $i=$ individual coping strategies.

\section{Model specification}

The dependent variable has a dichotomous nature. Binary logistic regression model was used to identify determinants of food security in the study area. The statistical similarities between logit and probit models make it difficult to choose between the two models. Maddala [26] indicated that logit model has the logistic distribution functions and probit model have cumulative normal functions. Furthermore, the logistic function has slightly heavier tails than the cumulative normal distributions. Therefore, binary logistic regression models were used (food insecure encodes ' 1 ' and food secure HHs encodes ' 0 '). The functional form of the logistic regression model was taken from [27] and presented the equation as follows:

$$
\left(P_{\mathrm{i}=} e^{\left(\mathrm{Y}=\frac{1}{\mathrm{x}_{\mathrm{i}}}\right)}=\frac{1}{1+e^{-\left(\beta_{0}+\beta_{1} \mathrm{x}_{1}\right)}}\right) .
$$

Here $P_{i}$ is the probability that a given $\mathrm{HH}$ is being food insecure. For simplicity, written as (1)

$$
\begin{aligned}
P_{\mathrm{i}} & =\frac{1}{1+e^{-z_{\mathrm{i}}}}, \quad \text { where } z \\
& =\beta_{0}+\beta_{1} x_{1}+\beta_{2} x_{2}+\beta_{3} x_{3}+\ldots+\beta_{\mathrm{n}} x_{\mathrm{n}} .
\end{aligned}
$$

The function of $\mathrm{n}$ explanatory variables i.e., $Z$ is calculated as the summation of $\beta$ 's at each exogenous variables $(\mathrm{x}) . \beta$ 's are population regression coefficients that are to be estimated from the data. The probability that a given $\mathrm{HH}$ food secure is:

$$
1-P_{\mathrm{i}}=\frac{1}{1+e^{\mathrm{z}_{\mathrm{i}}}} .
$$

Therefore, the odds ratio in favor of food insecure is

$$
\frac{P_{\mathrm{i}}}{1-P_{\mathrm{i}}}=e^{\mathrm{z}_{\mathrm{i}}} .
$$

Taking the natural logarithm of (4) we obtain,

$$
\begin{aligned}
L_{\mathrm{i}}= & \ln \left(\frac{P_{\mathrm{i}}}{1-P_{\mathrm{i}}}\right)=Z_{\mathrm{i}} \\
= & \beta_{0}+\beta_{1} x_{1}+\beta_{2} x_{2}+\ldots+\beta_{12} x_{12}+U_{\mathrm{i}}, \\
L_{\mathrm{i}}= & \ln \left(\frac{P_{\mathrm{i}}}{1-P_{\mathrm{i}}}\right)=Z_{\mathrm{i}} \\
= & \beta_{0}+\beta_{1} x_{1}+\beta_{2} x_{2}+\beta_{3} x_{3}+\beta_{4} x_{4}+\beta_{5} x_{5} \\
& +\beta_{6} x_{6}+\beta_{7} x_{7}+\beta_{8} x_{8}+\beta_{9} x_{9}+\beta_{i} x_{\mathrm{i}}+U_{\mathrm{i}},
\end{aligned}
$$

where $L_{\mathrm{i}}$ is the $\log$ of the odds ratio, $Z_{\mathrm{i}}$ is the function of n explanatory variables, $P_{\mathrm{i}}$ is the probability of being food insecure, $1-\mathrm{P}_{\mathrm{i}}$ is the probability of being food secure, $\beta_{0}$ is the intercept of the equation, $\beta_{1, \beta_{2} \ldots} \beta_{\mathrm{xi}}$ and $U \mathrm{i}$ are residual term and $x_{\mathrm{i}}^{\prime}$ s are the exogenous variables included in the model.

\section{Age of HH head (AHH)}

It is a continuous variable measured in years of $\mathrm{HH}$ head. As ages of HHs increased, it is assumed that farmers could acquire more knowledge and experience easily. So, they adopted modern technology. They are more risk averter, and their chance to become more food secure increases with age [28]. It is expected a negative relationship between age of $\mathrm{HH}$ head and food insecurity level.

\section{The education of HH head (EDUHH)}

It is a continuous variable measured by year of schooling. Educated HHs easily adopt different farming technologies and close to technology updates which become make them more risk aversive that strongly determines $\mathrm{HH}$ food security level [29]. In this study, $\mathrm{HH}$ head education level is expected to have a negative effect on the status of $\mathrm{HH}$ food insecurity.

\section{Sex of HH head (SEXHH)}

It is a dummy variable (i.e.1if it is female and 0 otherwise). Male-headed HHs have more access to agricultural technologies and off-farm activity than the female-headed HHs that make them involve in diversified income sources [30]. In this study, sex of $\mathrm{HH}$ head is expected to have positive effect on status of $\mathrm{HH}$ food insecurity.

\section{Family size of HH head (FSHH)}

It is a continuous variable that measures adult equivalent that live and depend in a single $\mathrm{HH}$. An increase in $\mathrm{HH}$ family size implies that more people are depending on limited resource of a single $\mathrm{HH}$ [11]. In this study, family size is expected to have a positive effect on $\mathrm{HH}$ food insecurity.

\section{Agro-ecology of land (AGRECO)}

This is a dummy variable ( 0 for lowland, 1 for midland agro-climatic zone). Lowlands were more likely to be food insecure as compared to midland. Rural $\mathrm{HH}$ in the midland were producing enset, potato and sweet potato that had helped them to become drought tolerant [31]. In this study, midland is expected to have a negative effect on $\mathrm{HH}$ food insecurity. 


\section{The number of oxen (TNO)}

It is a continuous variable measured in number. Oxen are the still the major source of agricultural power in most developing countries. Major successes of the agricultural activities are directly or indirectly supported by available oxen at $\mathrm{HH}$ level. Thus, the number of oxen available to the $\mathrm{HH}$ increases the probability of the $\mathrm{HH}$ being food secure [32]. It is expected that number of oxen owned have negative effect on the status of $\mathrm{HH}$ food insecurity.

\section{Tropical livestock unit (TLU)}

It is a continuous variable measured in TLU. HHs with large livestock size are less vulnerable to food insecurity [33]. It is expected that the number of TLU have negative effect on the status of $\mathrm{HH}$ food insecurity.

\section{Use of chemical fertilizer (UCF)}

It is a dummy variable taking the value of 1 if a farmer was being used fertilizer and 0 otherwise. It can increase agricultural productivity by boosting overall production and contributes to attaining food security at the $\mathrm{HH}$ level [11]. It is expected to have negative relationship between Uses of chemical fertilizer and status of $\mathrm{HH}$ food insecurity.

\section{Drought-tolerant seeds (DRRESEED)}

It is a dummy variable that takes a value of 1 if farmers used improved seeds and zero, otherwise. $\mathrm{HH}$ that uses improved seeds is expected to be more food secure than the non-users [31]. It is expected a negative relationship between drought-tolerant seeds and status of $\mathrm{HH}$ food insecurity.

\section{Soil and water conservation measures (SWC)}

It is a dummy variable 1 if a $\mathrm{HH}$ is practicing soil and water conservation and 0 otherwise. Soil and water conservation practices have been helping farmers to mitigate land degradation problem through maintaining soil fertility, which increases crop production and increases soil fertility. Erosion and soil degradation are among the major constraints of crop production [31]. Soil and water conservation has negative effect on status of $\mathrm{HH}$ food insecurity.

\section{Distance to nearest market (DISTMKT)}

It is a continuous variable measured by minute. $\mathrm{HHs}$ who has proximity to the market center have a better chance to improve their income. Distance to market and food insecurity have a positive relationship [29]. Distance to nearest market expected to have a positive effect on the status of $\mathrm{HH}$ food insecurity.

\section{Credit amount (CREDAMO)}

It is a continuous variable. Amount of credit provided for the purpose of consumption or acquisition of agricultural inputs can help farmers to improve agricultural productivity. Furthermore, access to credit does initiate investment in different farm and non-farm activities and achieve food security [34]. Amount of credit is expected to have a negative effect on the status of $\mathrm{HH}$ food insecurity.

\section{Receiving remittance (REMAMO)}

It is a continuous variable. It is assumed that HHs that are accessible to financial support are able to buys necessary food and agricultural input [35]. Receiving remittance has negative relationship with the statusof $\mathrm{HH}$ food insecurity.

\section{Productive safety net program participation (PSNP)}

It is a dummy variable for which value 1 is assigned was participate in the program, 0 otherwise. Farmer's participation in safety net program can protect asset depletion at the $\mathrm{HH}$ level and create communal assets at the community level. HHs who participates in the safety net program are obtaining food and cash aid frequently as compared to other groups. Productive safety net program participation was expected to have negative effect on the status of $\mathrm{HH}$ food insecurity.

\section{Access to climatic information (CLMATE)}

It is a dummy variable $1 \mathrm{HH}$ who have access to climatic information, 0 otherwise. Farmers who had access to climatic information had a better intensity towards embracing food security. Information on source of drought-tolerant crop varieties, methods of soil conservation and use of irrigation can support $\mathrm{HH}$ food security level [36]. It has a negative effect on the statusof $\mathrm{HH}$ food insecurity.

\section{Size of cultivated land (CULLAND)}

It is a continuous variable measured in a hectare. The possibility of harvesting higher yield directly related with size of cultivated land [29,37]. It has a negative effect on the statusof $\mathrm{HH}$ food insecurity.

\section{Access to irrigation (IRRIGA)}

It is a dummy variable (receiving support were code with a numeric value 1 and 0 if otherwise). Irrigation reduces the risk of crop failure and the increment in 
Table 2 Relationship between discrete variables and HH food security status ( $N=200 ; F S=72 ; F I S=128$ )

\begin{tabular}{|c|c|c|c|c|}
\hline Variable & Categories & $\begin{array}{l}\text { FS } \\
(\%)\end{array}$ & $\begin{array}{l}\text { FIS } \\
(\%)\end{array}$ & $x^{2}$ \\
\hline \multirow[t]{2}{*}{ Agro-ecology } & Lowland & 42 & 44 & 0.0402 \\
\hline & Midland & 48 & 46 & \\
\hline \multirow[t]{2}{*}{ Soil and water conservation } & No & 26 & 83 & 64.68 \\
\hline & Yes & 74 & 17 & \\
\hline \multirow[t]{2}{*}{ Sex of $\mathrm{HH}$} & Male & 56 & 66 & 2.083 \\
\hline & Female & 44 & 34 & \\
\hline \multirow[t]{2}{*}{ Agricultural extension } & No & 33 & 10 & $14.004^{* * *}$ \\
\hline & Yes & 67 & 90 & \\
\hline \multirow[t]{2}{*}{ Access to irrigation } & No & 80 & 51 & $18.557^{* * *}$ \\
\hline & Yes & 20 & 49 & \\
\hline \multirow[t]{2}{*}{ Provision of drought-resistant seed } & No & 84 & 30 & $58.66^{* * *}$ \\
\hline & Yes & 26 & 70 & \\
\hline \multirow[t]{2}{*}{ Productive safety net program participation } & No & 64 & 60 & 0.3704 \\
\hline & Yes & 36 & 40 & \\
\hline \multirow[t]{2}{*}{ Chemical fertilizer } & No & 84 & 30 & $25.930^{* * *}$ \\
\hline & Yes & 26 & 70 & \\
\hline \multirow[t]{2}{*}{ Climatic Information } & No & 75 & 25 & $48.625^{* * *}$ \\
\hline & Yes & 25 & 75 & \\
\hline
\end{tabular}

*** Significant at $1 \% \times 2$ chi-square

yields can be substantial if properly managed thus it can ensure food security for farming $\mathrm{HHs}$ [30]. It has expected to have a negative effect on $\mathrm{HH}$ food insecurity.

\section{Access to extension service (EXN)}

It is a dummy variable assigned the value label 1 for $\mathrm{HHs}$ were access to adequate agricultural extension service and 0 otherwise. Farmers who got support from extension agents are likely to improve their knowledge of using and managing their inputs very well as compared to farmers who don't get the service. This can probably improve their productivity and able them to tackle challenges which can minimize the probability of being food insecure [38]. Access to extension service has negative effect on status of $\mathrm{HH}$ food insecurity.

Table 3 Relationship between continuous variables with $\mathrm{HH}$ food security status $(\mathrm{N}=200 ; \mathrm{FS}=72 ; \mathrm{FIS}=128)$

\begin{tabular}{|c|c|c|c|c|c|c|}
\hline \multirow[t]{3}{*}{ Variable } & \multicolumn{4}{|c|}{ Food Security status } & \multirow{3}{*}{$\begin{array}{l}\text { Total } \\
\text { Mean }\end{array}$} & \multirow[t]{3}{*}{ Tvalue } \\
\hline & \multicolumn{2}{|l|}{ FIS } & \multicolumn{2}{|l|}{ FS } & & \\
\hline & Mean & $\mathrm{SD}$ & Mean & SD & & \\
\hline Age of the $\mathrm{HH}$ & 39.67 & 6.98 & 48.68 & 6.93 & 42.92 & $8.76^{* * *}$ \\
\hline Education status of $\mathrm{HH}$ head & 2 & 1.91 & 6 & 3.76 & 4 & $13.707^{* * *}$ \\
\hline Family size & 8 & 1.98 & 6 & 1.97 & 7 & $-4^{* * *}$ \\
\hline Number of oxen & 0.234 & 0.46 & 1.375 & 0.72 & 0.625 & $13.63^{* * *}$ \\
\hline Cultivated land size in $\mathrm{Ha}$ & 0.4 & 0.34 & 0.7 & 0.46 & 0.515 & $4.975^{* * *}$ \\
\hline Tropical livestock unit (TLU) & 3.16 & 3.09 & 4.29 & 3.38 & 3.57 & $2.38^{* *}$ \\
\hline Distance to the market & 86 & 49 & 47 & 46 & 72 & $-5.493^{* * *}$ \\
\hline Credit amount & 398 & 1062 & 2142 & 2789 & 1026 & $6.31^{* * *}$ \\
\hline Remittance received & 369 & 1209 & 2499 & 3528 & 1136 & $6.22^{* * *}$ \\
\hline Income from off-farm activities (ETB) & 1457 & 2370 & 2799 & 3044 & 1737 & $4.27^{* * *}$ \\
\hline
\end{tabular}

\footnotetext{
*** Significant at $1 \%$
}

** Significant at 5\%

$S D$ standard deviation, $H H$ household, ETB Ethiopian birr 


\section{Off-farm activities and non- farm activity (OFFANO)}

It is a continuous variable measured in ETB. HH head who engages in different means of income generation earn more income and has great chances of being food secure [28]. It is expected to have a negative effect between off-farm activities and non-farm activity and status of $\mathrm{HH}$ food insecurity.

\section{Results}

\section{Household food insecurity status}

Table 1 described about HHs' food security status of the study area. Among the total $200 \mathrm{HHs}$, following the recommended levels of food insecurity calculation, we categorized the HHs in to two groups (Food secure; Food insecure). The study indicated that $128(64 \%)$ of the total HHs were food insecure. These HHs daily consumption level is below $2100 \mathrm{kcal}$. Average consumed kilocalories of the respondent $\mathrm{HHs}$ was 1966.82 kilocalorie per adult equivalency $(\mathrm{S} . \mathrm{D}=893.05)$ which was below the national recommended kilocalories (2100) and minimum and maximum kilocalories of sample HHs are 432.86and 5271, respectively.

\section{Relationship between discrete variables and food insecurity status}

Relationship between discrete variables and food insecurity status is presented in Table 2. Different discrete variables were tested for the present of significance relationship with HH's food insecurity status. The proportion of female-headed HHs was higher in both categories $(44 ; 34 \%)$. Based on the result of the study, agricultural extension, access to irrigation, adoption of drought-resistance seed, application of chemical fertilizer and availability of climate information showed significant relationship $(P \leq 0.01)$ with the food insecurity status of the $\mathrm{HH}$. The study also indicated that food secure HHs were involving less (17\%) in soil and water conservation works as compared to food in secure $(74 \%)$. The proportion of male-headed and female-headed food insecure HHs was 56 and $44 \%$.

\section{Relationship between continuous variables and $\mathrm{HH}$ food insecurity}

Table 3 presents the relationship between continuous variables and $\mathrm{HH}$ food insecurity. All of the studied continuous variables showed significant relationship $(P \leq 0.05 ; P \leq 0.01)$ with $\mathrm{HH}$ food insecurity. The mean age of food secure (48.68) $\mathrm{HH}$ is higher as compared to food insecure groups (39.67). A vast variation in the number of oxen, the number of livestock respondents own and the size of land cultivated by the two groups was

Table 4 Marginal effects after binary logit model output $(N=200)$

\begin{tabular}{|c|c|c|c|c|}
\hline Variables & Marginal effect (dy/dx) & SE & Z & $P$ value \\
\hline AGRECO & -0.3380 & 0.1697 & -1.99 & $0.046^{* *}$ \\
\hline SEXHH & 0.4229 & 0.1569 & 2.69 & $0.007^{* * *}$ \\
\hline $\mathrm{AHH}$ & -0.02216 & 0.01219 & -1.82 & $0.069^{*}$ \\
\hline EDUHH & -0.09170 & 0.0424 & -2.16 & $0.031^{* *}$ \\
\hline $\mathrm{FSHH}$ & 0.00669 & 0.04237 & 0.16 & 0.874 \\
\hline TNO & -0.46254 & 0.1636 & -2.83 & $0.005^{* * *}$ \\
\hline TLU & $0.02,469$ & $0.03,045$ & 0.81 & 0.417 \\
\hline UCF & 0.02119 & 0.0929 & 0.23 & 0.820 \\
\hline DRRESEED & -0.14274 & 0.2199 & -0.65 & 0.516 \\
\hline SWC & $-0.35,550$ & $0.15,555$ & -2.29 & $0.022^{* *}$ \\
\hline DISTMKT & 0.001625 & $0.00,202$ & 0.80 & 0.421 \\
\hline CREDAMO & -0.000135 & $0.00,008$ & -1.66 & $0.097^{*}$ \\
\hline REMAMO & -0.000114 & 0.00006 & -1.85 & $0.064^{*}$ \\
\hline PSNP & $0.16,150$ & 0.17742 & 0.91 & 0.363 \\
\hline CLMATE & -0.0700048 & 0.19035 & -0.37 & 0.713 \\
\hline CULLAND & $-0.50,902$ & $0.20,214$ & -2.52 & $0.012^{* *}$ \\
\hline IRRIGA & $0.2,370,844$ & 0.17975 & 1.32 & 0.187 \\
\hline EXN & $0.154,161$ & $0.20,357$ & 0.76 & 0.449 \\
\hline OFFANO & $8.65 e-06$ & 0.00004 & 0.24 & 0.813 \\
\hline Number of observation & 200 & Pseudo R2 & 0.7286 & \\
\hline LR chi2(19) & 190.44 & Log likelihood & -35.464524 & \\
\hline Prob > chi2 & 0.0000 & & & \\
\hline
\end{tabular}

*** ,** * significant at 1, 5 and 10\% probability level, respectively; SE represents Standard Error 
Table 5 Rural HHs coping strategies index $(N=200)$

\begin{tabular}{|c|c|c|c|}
\hline Local coping strategies & CSI & WMS & Rank \\
\hline Rely on less preferred and cheap food & 457 & 2.285 & 1 \\
\hline Participating in off-farm activity like wage employment & 277 & 1.385 & 2 \\
\hline Borrow food from friends or relatives & 206 & 1.03 & 3 \\
\hline Restrict food consumption of adults to feed children & 201 & 1.005 & 4 \\
\hline Reduce the number of meals and limit the proportion size of a meal of household & 200 & 1 & 5 \\
\hline Seasonal migration to other place & 194 & 0.97 & 6 \\
\hline Receiving support from PSNP and other NGO in form of cash and kind & 170 & 0.85 & 7 \\
\hline
\end{tabular}

CSI represents coping strategy index; WMS represents weighted mean score

observed between the two groups. The average status of education for food secure HHs were 6 grade which was higher than the food insecure HHs i.e., 2nd grade. Food secure $\mathrm{HHs}$ were participated in different off-farm activities to generate income (2799 ETB) as compared to food insecure HHs (1457 ETB). The amount of credit and remittance provided for Food secure HHs were so much higher as compared to food insecure HHs. In addition, family size and distance to the market were also showed significant effects $(P \leq 0.01)$ on the $\mathrm{HH}$ food insecurity and positive relationship with mean of $\mathrm{HH}$ food insecurity and significant at 1 percent significant level.

\section{Marginal effect values for variables under study}

The present study indicated that agro-ecology, sex of $\mathrm{HH}$ head, age of $\mathrm{HH}$ head, educational status of $\mathrm{HH}$ head, number of oxen owned, soil and water conservation practices, availability of credit and remittance and size of cultivated land were showed a significant relationship with level of food insecurity at $P \leq 0.05 ; P \leq 0.01$. Negative relationship was observed with all the significant variables except sex of HH head (Table 4).

\section{Local coping strategies to food insecurity}

Rank for different local coping strategies towards food insecurity is presented in Table 5. Relying on less preferred and cheap food was ranked first 457(2.285) among other local coping strategies followed by participating in off-farm activities 277(1.385), borrow food 206(1.03), and restrict food consumption 201(1.005).

\section{Discussion}

The ever-continuing hunger and undernourishment is the biggest challenge to numerous communities and $\mathrm{HHs}$ found in different part of Ethiopia. The severity of the situation is varied due to different determinant factors. Female and food insecure HHs' proportion in this study area is very high as compared to the national average i.e., $20.6 \%$ [39]. This difference might arise due to the implemented selection criteria. The selection criteria is based on the frequency of drought occurrence, level of food insecurity and relative number of safety net program beneficiaries. This can boost the number of vulnerable groups which can get in to the selection process. Undertaking investigation on the basic determinant factors and local coping strategies can help to spot out concrete recommendation which further guide projects working food insecurity. Due to the escalating coverage of agricultural sectors to risks, the adoption of efficient strategies and policies to cope with risks has been done taken as primary agenda in different developing countries [40, 41]. Food security level is directly related to food availability and consumption level at HH level [42]. This study cites a base line to categorize food security level of HHs. Households who consume below the minimum requirement i.e., 2100 kilocalorie per day as food insecure, and those HHs who consume equivalent to and above the minimum requirement considered as food secure. Based on this cut-off or benchmark, about $64 \%$ of the respondents are food insecure. Average consumed kilocalories of the responding HHs i.e., 1966.82 kilocalorie per adult equivalency $(S . D=893.05)$ is below national recommended kilocalories [4] (Table 6).

Investigating the critical variables which are highly affected by food insecurity can be useful to bring sustainable change in relation to food security. In this study, discrete data such as agro-ecology, sex of respondent, soil and water conservation, are identified to have a significant effect $(\mathrm{P}<0.05)$ on the $\mathrm{HH}$ food insecurity. This might be due to majority of the variables directly or indirectly affect productivity of cultivated land. Continuous variables such as age of $\mathrm{HH}$ heads, education status of $\mathrm{HH}$ heads, and cultivated land size in hectare, number of oxen, credit amount, and remittance received have also showed significant effect $(P \leq 0.05)$ on $\mathrm{HH}$ food insecurity. Majority of agricultural inputs information can be accessed from different Medias, and farmer's information acquiring capacity can rely with their education level. Even if majority of the developing countries are still livestock dependent for different purposes such as 
Table 6 Expected sign of the independent variable with the dependent variable

\begin{tabular}{|c|c|c|c|}
\hline Variable acronyms & Independent variables & Measurement & $\begin{array}{l}\text { Status of } \\
\text { HHs food } \\
\text { insecurity }\end{array}$ \\
\hline AGRECO & Agro-ecology & It is dummy 0 was assigned for lowland, 1 was assigned for midland & - \\
\hline SEXHH & Sex of HHs head & It is a dummy variable (i.e. 1 if it is female and 0 otherwise & + \\
\hline AGEHH & Age of HHs head & Continuous measured with age & - \\
\hline EDUHH & Education $\mathrm{HH}$ s head & Continuous measured with year of schooling & - \\
\hline FSHH & Family of size HHs head & Continuous measured with adult equivalency & + \\
\hline TNO & Number oxen & Continuous measured in number of oxen & - \\
\hline TLU & Tropical livestock unit & Continuous measured with tropical livestock unit & - \\
\hline UCF & Use of chemical fertilizer & $\begin{array}{l}\text { It was a dummy variable taking the value of } 1 \text { if a farmer was being used ferti- } \\
\text { lizer and } 0 \text { otherwise }\end{array}$ & - \\
\hline DRRESEED & Drought-tolerant seeds & $\begin{array}{l}\text { It is a dummy variable that takes a value of } 1 \text { if farmers used improved seeds } \\
\text { and zero, otherwise }\end{array}$ & - \\
\hline SWC & Soil and water conservation & $\begin{array}{l}\text { It is dummy variable } 1 \text { if a } \mathrm{HH} \text { is practicing soil and water conservation and } 0 \\
\text { otherwise }\end{array}$ & - \\
\hline DISTMKT & Distance to nearest market & It is a continuous variable measured minute & + \\
\hline CREDAMO & Credit amount & Continuous variable measured in Birr & - \\
\hline REMAMO & Receiving remittance amount & Continuous variable measured in Birr & - \\
\hline PSNP & Productive safety net program & $\begin{array}{l}\text { This is a dummy variable for which value } 1 \text { is assigned was participate in the } \\
\text { program, } 0 \text { otherwise }\end{array}$ & - \\
\hline CLMATE & Access to climatic information & It is dummy variable $1 \mathrm{HH}$ who have access to climatic information, 0 otherwise & - \\
\hline CULLAND & Size of cultivated land & Continuous measured with hectare & - \\
\hline IRRIGA & Access to irrigation & $\begin{array}{l}\text { It is dummy variable (receiving support were code with a numeric value } 1 \text { and } \\
0 \text { if otherwise) }\end{array}$ & - \\
\hline EXN & Access to extension service & $\begin{array}{l}\text { It was dummy variable assigned the value label } 1 \text { for } \mathrm{HH} \text { s were access to } \\
\text { adequate agricultural extension service and } 0 \text { otherwise }\end{array}$ & - \\
\hline OFFANO & Off- and non-farm & Continuous measured in Birr & - \\
\hline
\end{tabular}

ploughing, source of fertilizer, source of fuel and source of food, among the livestock group, oxen has the significant importance in majority of the agricultural activities. Similarly, HH's oxen holding capacity have negative relationship with $\mathrm{HH}$ food insecurity status significance at less than $1 \%$ probability level. The probability of being food insecure decreases by 46.2 percent, as a number of oxen increases by one. The model output indicates that conformity with a study by $[11,32]$.

The present study indicates that HHs who lives in midland agro-eciology is less likely to be affected by food insecurity than those who live in the lowland. The marginal effect estimation indicates that all other things constant, the probability of being food insecure in the midland is decreased by $33.8 \%$. This result is in line with studies done by [43]. The probability of female $\mathrm{HH}$ head being food insecure is increased by $42.3 \%$. This might be due to male-headed HHs are likely to access education and participate more in different community works. This can make them more experienced in tackling food insecurity through accessing other income generation means and adoption of new agricultural technologies as compared to female groups. This result is in conformity with the study done by [30, 31]. Age of HH head has a negative relationship with food insecure. This estimate indicated that food insecurity decreases with increase in age of $\mathrm{HH}$ head. The probability of being food insecure decreases by $2.21 \%$ as the age of the $\mathrm{HH}$ is increased by one year. The above finding is in line with [28]. Household heads level of education can let them to easily adopt different technologies to update the conventional farming system and improve agricultural productivity. This study indicates that one additional schooling year can minimize the probability of $\mathrm{HH}$ to be food insecure by $9.1 \%$ or, additional year of schooling reduces the likelihood of food insecurity by a probability of 0.092 . This model output is in agreement with the finding of $[9,44]$. All other things are constant, the probability of being food insecure for HHs who have not practiced soil and water conservation decreases by $35.5 \%$. This model output is similar with the finding of [33]. Household's access to credit services can decreases the food insecurity incident by $0.0135 \%$ as credit amount increases by one Birr (ETB). This result is similar with [45]. The probability of being food insecurity is decreased by $0.0114 \%$ as HHs receives one birr increase in remittance. This implies that receiving remittance has 
been helping $\mathrm{HH}$ heads to decrease their food insecurity level. The result is similar with [35] in rural northern hinter land of Pakistan. Similarly, all other things constant, the probability of being food insecurity decrease by $50.9 \%$ as the size of cultivated land amount increases by one hectare. This result is in line with [11] in Oromia region of Ethiopia.

Agricultural risks are troublesome to small-scale farmers in developing countries. The types and severity of the risks confronting farmers vary with the farming system and with the climate, policy, and institutional based setting [46]. Strategies that have been acquired through long years of farmers experience is relevant to deal with the existsing challenges. Farmers, rural institutions and lenders encompass, over generations, develop ways of reducing and coping with risk. For all, experience plays a substantial role in decision-making process of averting and minimizing risks in farming activities. Farmers' participation in crop insurance is increased with experience [47]. Farmers who rely on traditional risk-coping strategies have been facing fundamental problem, but nearly all kinds of farmers affect by production and price risks simultaneously [48]. Traditional risk management arrangements frequently fail to provide an adequate safety net for the poor, and limited in its ability to manage disastrous risks. Similarly, private side role in insuring farmers and rural communities against agricultural risks has also been insignificant [49]. In developing countries, agricultural risks are treated majorly by food aid from GO and NGOs after the occurrence. Massive food aid became ineffective instrument in responding to such problems, and the percentage of food-insecure HHs never shows a decline [43]. Agricultural risks are still managed with coping strategies rather than risk-reducing strategies. Most farmers in Ethiopia are producing just for subsistence purpose. Though risk-reducing strategies are effective in addressing many production and market risks, they are costly even for average income generating farmers. It might force them to abandon their most profitable alternatives. In this study, eleven different coping strategies are very prominent among all available local coping strategies towards tackling food insecurity. Among them, relying on less preferred and less expensive food ranks first (2.285). Frequent use and farmer's preference towards this strategy might be primarily linked with higher foodstuffs price (inflation of food price). The second ranked strategy is participating in off-farm activities (1.385). Information collected from FGD and KII indicates that the major off-farm activity in which $\mathrm{HHs}$ has been generating income is through day labor and land rental. The third (1.03) strategy is borrowing food from friends or relatives. This shows social relationship of the communities is very strong even in the worst times.
However, FGD participants have witnessed that lending food from the collected small crop yield to food insecure $\mathrm{HHs}$ have been making the situation more severe because probability of repaying their debt in the coming year is very low. This can also be additional factor that can increase the number of food insecure HHs. Restricting food consumption as coping strategy has been directly affecting children who stay at home. Food insecured adults have the chance to identify food source while they are working in different off-farm activities. If the situation is so much worse, HHs have been forced to migrate to other places to save their lives. Though Ethiopia has adopted a food security strategy in 1996, due to a reduction in the amount of annual rainfall, some regions of the country are still emergency relief assistance dependent. More than half (around 3.7 million people) of Ethiopian Somali national region population were aid by WFP's emergency relief assistance due to rainfall reduction in 2016 [50]. Technology-based risk-coping strategies such as designing a suitable weather index by considering the different climatic variables can help to forecast spatial pattern of crop loss in an area [51]. It is also very crucial to develop and implementing public policy which give emphasis to agricultural risk management for food security [52]. Intervention implementation plans in such area by GO and NGO have been done poorly. It is mostly become active when the situation is become worse and when it reaches to the status of hunger. Due to the above reasons, $\mathrm{HHs}$ trust on those intervening organization is very weak. In addition, very fragile risk-sharing arrangements for small-scale farmers in developing countries increase the burden of risk for the individual farmer and destabilize farm incomes [46].

The prevalence of risk in agriculture is not new and farmers, rural institutions and lenders over generations have been developing ways of reducing and coping with risk. Despite these developments, agricultural insurance remains far too small to meet the risk management needs of most farmers and rural people in developing countries. This is basically due to crop insurance demands farmers' experience, subsidies and wide set of contracts which help them to make decision [53]. Moreover, [47] indicate that entry and exit decisions remain crucial to enhance crop insurance. Policymakers should take this dimension into consideration to improve the efficacy of planned interventions giving due emphasis to role of information, experience and farm size. Traditional risk management mechanisms are not sufficient to shield farmers from frequently observed food insecurity. Alternatives that are supported by technology and experience can be more efficient coping up strategies in developing countries. 


\section{Conclusion}

The study concluded that $64 \%$ of the participated HHs in this study was food insecure. All measured continous variables showed a significant relation ship with status of food security.The level of food security was also determined by availability of agricultural extension, access to irrigation, provision of drought-resistant seed, access to chemical fertilizer and climate information. Age of $\mathrm{HH}$ head, sex of $\mathrm{HH}$ head, education status of $\mathrm{HH}$ head, size of cultivated land, number of oxen, soil and water conservation, access to remittance and credit amount showed a significant relationship with food insecurity. Among the significant relationship, negative relationship was observed between food insecurity and majority of tested variables (i.e., agro-ecology, education status, number of oxen owned, soil and water conservation, access to credit and remittance and size of cultivated land) except being became male $\mathrm{HH}$ heads. Various local food insecurity coping strategies had been used by HHs in the study area but the first three ranks were relying on less preferred and cheap food, participating in off-farm activity and borrowing food from friends or relatives, respectively. The study recommends that intervention that provides support to farms in the area of enhancing agricultural productivity through agricultural extension; increase access to irrigation, improved seed, fertilizer and chemical fertilizer can minimize the food insecurity level of HHs. Furthermore, special attention should also be given to female and uneducated HHs, particularly in the lowland agroecology. Efforts to increase the size of cultivated land per head, number of oxen and livestock owned should be invested. Governments and non-governmental organizations interventions should focus on improving access to agricultural technologies basically on improved seed provision, soil and water conservation, irrigation technology rather than sticking to provision of remittance and credit.

\begin{abstract}
Abbreviations
CSI: Coping Strategy Index; ETB: Ethiopian Birr; FGD: Focus Group Discussion; GO: Government; GTP: Growth and Transformation Plan; Kcal: Kilocalorie; HH: Household; KIl: Key Informant Interview; NGO: Non-Governmental Organization; PA: Peasant Association; PIF: Policy and Investment Framework; PRA: Participatory Rural Appraisal; SD: Standard Deviation; SE: Standard Error; TLU: Tropical Livestock Unit; WFP: World Food Programme; WMS: Weighted Mean Score.
\end{abstract}

\section{Acknowledgements}

The authors pass their acknowledgements to zonal experts, extension agents and respondents who have been helping us at the time of data collection.

\section{Author contributions}

MM conducted the field research, analyzed the data, and drafted the manuscript. MM, MT and MA designed the research, interpreted the results, and were involved in the manuscript writing. All authors revised the manuscript and read and approved the final version.
Funding

Not applicable.

\section{Availability of data and materials}

The datasets used and/or analyzed during the current study are available from the corresponding author on reasonable request.

\section{Declarations}

Ethics approval and consent to participate

Not applicable.

Consent for publication

Not applicable.

\section{Competing interests}

The authors declare that they have no competing interests.

\section{Author details}

${ }^{1}$ College of Agriculture and Natural Resource, Wolkite University, P.O.box 07, Wolkite, Ethiopia. ${ }^{2}$ College of Business and Economics, Arbaminch University, Arbaminch, Ethiopia.

Received: 4 September 2020 Accepted: 1 March 2021

Published online: 07 August 2021

\section{References}

1. Belachew D. Transitory coping strategies of food insecure smallholder farmer households: The Case of Ilu Gelan District, West Shoa Zone, Oromia Reginal State. Ethiopia Agric Food Security. 2018;7(1):70. https://doi. org/10.1186/s40066-018-0204-2.

2. Food and Agricultural Organization (FAO). The state of food insecurity in the world, . The multiple dimensions of food security. Rome: FAO; 2013. p. 2013.

3. Mustapha M., Kamaruddin RB, Dewi S. Assessing the food security determinants among rural households in Kano, Nigeria AJAERD, (October). 2018. www.premierpublishers.org,

4. Africa food security and hunger (AFSH). Hunger/undernourishment scorecard, 1-5. 2014.

5. Africa Development Bank(ADB). Africa food security brief: Special focus on climate change.Africa food security statistics department, Issue No 5 , April 2014.

6. USAID. Food assistance fact sheet total contributions per fiscal year report, 2018

7. Angassa A, Beyene F. Current range condition in southern Ethiopia in relation to traditional management strategies: the perceptions of Borana pastoralists. Tropical Grasslands. 2003;37:53-9.

8. Tilahun M, Angassa A, Abebe A. Community based knowledge towards rangeland condition, Climate change and coping strategies: The case of Afar Pastoralists. Ecol Process. 2017;6(29):1-13. https://doi.org/10.1186/ s13717-017-0094-4

9. Eden M, Nigatu R, Ansha Y. Analyiss of Household levels determinants and coping mechanisms of food insecure households in Southern Ethiopia. DCG Report No. 55; 2009.

10. Habtamu A. Transitory food insecurity and coping strategies in north western Ethiopia. In: Sixth International Conference in Agricultural Statistics, October, 2013.

11. Ahmed K, Jema H, Lemma Z. Determinants of food insecurity and coping strategies of rural Households: the case of Shalla District, West Arsi Zone, Oromia Region, Ethiopia. J Dev Agric Econ. 2018;10(6):200-12. https://doi. org/10.5897/JDAE2018.0933.

12. Angassa A, Oba G. Relating long term rainfall variability to cattle population dynamics in communal rangelands and a government ranch in southern Ethiopia. Agric Syst. 2007;94:715-25.

13. Angassa A, Oba G, Stenseth NC. Community- based knowledge of indigenous vegetation in arid African landscapes. J Sustain Dev. 2012:8:70-85. 
14. Desta D, Belta A. Review on impact of small scale irrigation in Household food security. Ethiopia J Econ Sustain Dev 2015; 6(21). Issn 222217000(paper); Issn 2222-2855 (online). 2015.

15. Central Statistics Agency(CSA). Agricultural Sample survey. 194p. 2017.http://www.csa.gov.et/text_files/2009_national_statistics.htm

16. Hadiya Zone Agricultural Development Office (HZADO). Annual Progressive Report of Analemmo Aricultural Development Office. Fonko: Unpublished. 2018.

17. Getachew O, Nuri K, Raya A, Basab D, Worku A, Francis OO. Bellmon analysis on crop availability and market study in Ethiopia. USAID. January, 2018.

18. Adinew L. Determinants and coping strategies of Household food insecurity: The Case of Rural Setting in Lemo Woreda. Hadiya Zone. 2007:67(6):14-21.

19. Deribe D. Assessment of factors affecting food insecurity in Shashogo Woreda selected Kebeles among rural farm households. Masters Thesis, Addis Ababa University, Ethiopia. 2018. http://localhost:80/xmlui/handle/ $123456789 / 14441$.

20. Analemmo Woreda Agricultural Development Office (AWADO). Annual Progressive Report of Analemmo Agricultural Development Office. Fonko: Unpublished. 2018.

21. Yamane T. Statistics, an introductory analysis. 2nd ed. New York: Harper and Row; 1967.

22. Israel GD. Determining sample size. University of Florida. PEOD6. Gainesville 32611. 1992

23. Ethiopian Health and Nutrition Research Institution(EHNRI). Kilocalories of different food groups. 2000.

24. Smith LC, A S. Measuring food security using Household expenditure surveys. Food security in practice technical guide series. Washington, D.C.: International Food Policy Research Institute, (January); 2007. pp 15-17.

25. Adebo GM, Falowo OO. rural household food security and coping strategies in south- west, nigeria : a gender differentials perspective. Food Sci Qual Manage. 2015;41:44-50.

26. Maddala GS, Lahiri K. Introduction-to-econometric-4th edition - Maddala. 2009: 654. ISBN: 978-0-470-01512-4.

27. Gujarati DN. Basic Econometrics. In: Science, vol 328, Fourth Edition. New York: McGraw-Hill; 2004. Doi: https://doi.org/10.1126/science.1186874.

28. Adugna E, Wagayehu B. Causes of Household food insecurity in Wolayta. Journal of Stored Products and Postharvest Research. 2012; 3(3), pp. 35-48, DOI: 10.5897/JSPPR11.069

29. Ermias $G$. An empirical examination of the determinants of food insecurity among rural farm Households: evidence from Kindo Didaye District of Southern Ethiopia. Bus Econ J. 2018;09(01):1-12. https://doi.org/10.4172/ 2151-6219.1000345.

30. Karale K. Household food security status and its determinants in rural Konso Woreda, Segen Area Peoples' Zone, Southern Ethiopia. Addis Ababa Univeristy, Msc. Thesis. 2015.

31. Abayineh A, Belay S. Assessment of Household food security in the face of climate change and variability in the upper Blue-Nile of Ethiopia vol 7. 2017. pp 285-300. Doi: https://doi.org/10.17265/2161-6264/2017.04.006 .

32. Yirgu HA. Determinants of food security in rural farm Households in Ethiopia, The Hague, The Netherlands, Masters Thesis. 2014.

33. Mequanent M, Esubalew T. Analysis of household level determinants of food security in Jimma Zone, Ethiopia. J Econ Sustain Dev. 2015;6(9):230-41.

34. Fekadu B, Mequanent M. Determinants of food security among rural Households of Central Ethiopia: Anempirical analysis. Q J Int Agric. 2010;49(4):299-318. https://doi.org/10.1108/03068290410546011.

35. Zhou D, Shah T, Ali S. Factors affecting Household food security in rural northern hinter land of Pakistan. J Saudi Soc Agric Sci. 2019;18(2):201-10. https://doi.org/10.1016/j.jssas.2017.05.003.
36. Nhemachena C, Hassan R. Micro-level analysis of farmers' adaptation to climate change in Southern Africa, (August). 2007.

37. Abdulla A. Determinants of Household food security and coping strategies: The case of Bule-Hora District. Oromia, Ethiopia: Borana Zone; 2015.

38. Hana ME, Dereje HB. Analysis of household food insecurity and its covariates in Girar Jarso Woreda, Oromia Regional State, Ethiopia. J Econ Sustain Dev. 2016;7(3). ISSN 2222-1700 (Paper) ISSN 2222-2855 (Online).

39. World Food Program(WFP). Food security bulletin: Food security monitoring system. Rome; 2016.

40. Sambotin D, Alda M, Toader C, lancu T. The risk management in agriculture. Lucrări Științifice Management Agricol. 2013;15(2):303.

41. Santeramo F G, Capitanio F, Adinolfi F. Integrating agricultural risks management strategies in selected EU partner countries: Syria, Tunisia, Turkey. Roman J Eur Affairs 2014;14(3). https://mpra.ub.uni-muenchen.de/58935/.

42. Sisha TA. Household level food insecurity assessment: Evidence from panel data. Ethiopia Sci Afr. 2020;7:2468-2276. https://doi.org/10.1016/j. sciaf.2019.e00262.

43. Mohammed A. Food Insecurity and copping Strategies of Agro Pastoral Households in Awbar Woreda, Ethiopian Somali Regional State. Masters Thesis. INDRA GANDHI NATIONAL OPEN UNIVERSITY. Addis Ababa, Ethiopia. 2016

44. Shishay K, Messay M. Determinants of rural Household food insecurity in Laelay Maichew Woreda Tigray, ethiopia. Afr J Agric Food Security. 2014:2(1):106-12.

45. Abebaw S. Dimensions and determinants of food insecurity among rural Household s in Dire Dawa. Eastern Ethiopia. 2003. https://doi.org/10. 1016/j.carres.2009.09.003.

46. Hazell PB, Pomareda C, Valdes A (eds) Crop insurance for agricultural development: issues and experience. Baltimore: Johns Hopkins University Press; 1986

47. Santeramo FG, Goodwin BK, Adinolfi F, Capitanio F. Farmer participation, entry and exit decisions in the Italian crop insurance programme. J Agric Econ. 2016;67(3):639-57. https://doi.org/10.1111/1477-9552.12155.

48. Hazell PB. The appropriate role of agricultural insurance in developing countries. J Int Dev. 1992;4(6):567-81.

49. Hess $U$, Hazell PB, Kuhn S. Innovations and emerging trends in agricultural insurance. Deutsche Gesellschaft für Internationale Zusammenarbeit (GIZ) GmbH; 2016.

50. World Food Program(WFP). WFP Ethiopia, Technical Report. April, 2016.

51. Biffis $E$, Chavez E. Satellite data and machine learning for weather risk management and food security. Risk Anal. 2017;37(8):1508-21.

52. Boyd $\mathrm{M}$, Wang $\mathrm{HH}$. The role of public policy and agricultural risk management in food security Public policy: implications for food security. China Agric Econ Rev. 2011. https://doi.org/10.1108/caer.2011.40603daa.001.

53. Santeramo FG. I learn, you learn, we gain experience in crop insurance markets. Appl Econ Perspect Policy. 2019;41(2):284-304.

\section{Publisher's Note}

Springer Nature remains neutral with regard to jurisdictional claims in published maps and institutional affiliations.

Ready to submit your research? Choose BMC and benefit from

- fast, convenient online submission

- thorough peer review by experienced researchers in your field

- rapid publication on acceptance

- support for research data, including large and complex data types

- gold Open Access which fosters wider collaboration and increased citations

- maximum visibility for your research: over $100 \mathrm{M}$ website views per year

At BMC, research is always in progress.

Learn more biomedcentral.com/submissions 